\title{
Barium in Stony Meteorites
}

\author{
Carleton B. Moore ${ }^{1}$ and Harrison Brown \\ Division of Geological Sciences \\ California Institute of Technology, Pasadena
}

\begin{abstract}
Absstract. Concentrations of barium have been determined spectrographically in 95 stony meteorites. The distribution of the concentration of barium in the chondritic falls appears to be log-normal in shape with a median of $4.5 \mathrm{ppm}$. The concentrations in the chondritic finds indicate a tetramodal distribution that may have resulted from terrestrial contamination, but that also may have been present initially. The fact that the finds represent a strongly selected sample of generally hard and resistant meteorites leaves the second alternative open as a distinct possibility.
\end{abstract}

Introduction. Values for the concentration of barium in stony meteorites were obtained by Von Englehardt [1936]. The most recent values have been obtained by Pinson et al. [1953] using spectrochemical techniques and by Hamaguchi et al. [1957] using neutron activation. In this work barium has been determined in a suite of ninety-five stony meteorites consisting of fortythree chondritic falls, forty-five chondritic finds, two carbonaceous chondrites, and five achondrites. In Table 1 the results of this work are compared with the earlier results.

The specimens, spectrographic equipment, and analytical techniques used by Moore and Brown [1962] in their study of the distribution of manganese and titanium were used in the present work. The concentrations of barium were within the limit of sensitivity under the conditions used and were determined by means of the emission line at $4554.0 \mathrm{~A}$.

The standard deviation from the mean in this work is estimated to be about 20 per cent. A major source of variation appears to be in the sampling.

Results. The concentrations of barium in the ninety-five stony meteorites are given in Table 2.

Figure 1 shows the frequency of occurrence versus the logarithm of the barium concentration for forty-three chondrite falls. The distribution appears to be log-normal in shape. The median is $4.5 \mathrm{ppm}$, the mode is $4 \mathrm{ppm}$, and the antilogarithm of the mean of the logarithm is $4.8 \mathrm{ppm}$.

\footnotetext{
${ }^{1}$ Now at Arizona State University, Tempe, Ari-
}

Figure 2 shows the frequency of occurrence versus the logarithm of the barium concentration for forty-five chondrite finds. It is difficult to assess whether the apparent tetramodal distribution is real or occurs by chance. The problem immediately arises as to whether the high barium concentrations in the finds are the result of terrestrial contamination or were present originally. Although the first alternative seems the more probable, the fact that the finds represent a strongly selected sample of hard resistant meteorites leaves the second alternative open as a distinct possibility.

The importance of carefully selecting samples to minimize the possibility of terrestrial contamination is well illustrated by our analyses of the Holbrook chondrite. A description of the samples used and their barium contents is given in Table 3. This fall consisted of many individual stones ranging in size from minute grains to a $6.6-\mathrm{kg}$ mass.

Some of the specimens were collected immediately after the fall; others were picked up as much as twenty years later. The histories of our particular samples are unknown. The large fluctuation in the barium concentrations obtained seems to indicate selective contamination. Whether the specimen of the Saratov chondrite (22 ppm Ba) has also had an opportunity to become contaminated is unknown.

In the absence of more data it seems reasonable to suspect that the high barium concentrations in the finds are the result of terrestrial contamination from the ground and that the best value for the concentration of barium in chondrites is about $4 \mathrm{ppm}$. This number is about 
TABLE 1. Barium in Stony Meteorites as Determined by Von Englehardt [1936], Pinson et al. [1953], and Hamaguchi et al. [1957]

\begin{tabular}{|c|c|c|c|c|}
\hline \multirow[b]{2}{*}{ Meteorite } & \multicolumn{4}{|c|}{ Barium, ppm } \\
\hline & Von E. & Pinson & Hamaguchi & $\begin{array}{l}\text { This } \\
\text { Paper }\end{array}$ \\
\hline \multicolumn{5}{|l|}{ Chondrites } \\
\hline L'Aigle & $3-10$ & & $\ldots$ & \\
\hline Knyahinya & $1-3$ & & $\ldots$ & 5 \\
\hline Holbrook & $3-10$ & 9 & 4.0 & $26^{*}$ \\
\hline Erxleben & $1-3$ & $\ldots$ & $\ldots$ & $\ldots$ \\
\hline Chantonnay & $1-3$ & $\ldots$ & $\ldots$ & $\ldots$ \\
\hline Barbotan & $1-3$ & $\ldots$ & $\ldots$ & $\ldots$ \\
\hline Aviles & $<1$ & & $\ldots$ & $\ldots$ \\
\hline Bjurböle & $<1$ & 8 & $\ldots$ & 5 \\
\hline Pultusk & $\ldots$ & 7 & $\ldots$ & 3 \\
\hline Homestead & $\ldots$ & 11 & $\ldots$ & \\
\hline Ransom & $\ldots$ & 7 & $\cdots$ & 28 \\
\hline Hayes Center & r $\ldots$ & 32 & $\ldots$ & 30 \\
\hline Waconda & $\ldots$ & 7 & $\ldots$ & $\ldots$ \\
\hline Assun & $\ldots$ & 8 & & $\ldots$ \\
\hline Forest City & $\ldots$ & 9 & 3.7 & 4 \\
\hline Hessle & $\ldots$ & 7 & $\ldots$ & $\ldots$ \\
\hline Kernouve & $\ldots$ & 6 & $\ldots$ & $\ldots$ \\
\hline Barratta & $\ldots$ & 7 & $\ldots$ & \\
\hline Mocs & $\ldots$ & 6 & $\ldots$ & 5 \\
\hline Tennasilm & $\ldots$ & 10 & $\ldots$ & $\ldots$ \\
\hline Monroe & $\ldots$ & 5 & $\ldots$ & \\
\hline Long Island & $\ldots$ & 100 & $\ldots$ & 190 \\
\hline Beaver Creek & $k \quad \ldots$ & 5 & $\ldots$ & $\ldots$ \\
\hline Lumpkin & $\ldots$ & 6 & $\ldots$ & $\ldots$ \\
\hline \multicolumn{5}{|l|}{ Cangas } \\
\hline de Onis & $\cdots$ & 5 & $\ldots$ & $\ldots$ \\
\hline Estacado & $\ldots$ & 6 & $\ldots$ & $\ldots$ \\
\hline Warrentown & & 5 & & $\ldots$ \\
\hline Modoc & $\ldots$ & $\ldots$ & 3.6 & 5 \\
\hline Richardton & $\ldots$ & $\ldots$ & 3.2 & 4 \\
\hline \multicolumn{5}{|l|}{ Nuevo } \\
\hline Laredo & $\ldots$ & .. & 46 & $\ldots$ \\
\hline
\end{tabular}

\section{Eucrites}

$\begin{array}{lllll}\text { Stannern } & 48 & \ldots & \ldots & \ldots \\ \text { Juvinas } & 10-30 & \ldots & \ldots & \ldots\end{array}$

Chladnites

Johnstown

5

2.5

Carbonaceous

Chondrites

Orgueil

$\ldots<1$

* Mean of eight samples; barium values were very erratic.
TABLE 2. Barium Concentrations in Stony Meteorites

\begin{tabular}{|c|c|}
\hline Meteorite & Barium, ppm \\
\hline \multicolumn{2}{|l|}{ Ordinary chondrite falls } \\
\hline Alexandrovsky & 10 \\
\hline Alfianello & 3 \\
\hline Allegan & 4 \\
\hline Beardsley & 5 \\
\hline Bjurböle & 5 \\
\hline Chateau Renard & 6 \\
\hline Colby, Wisconsin & 4.5 \\
\hline Dhurmsala & 6 \\
\hline Elenovka & 5 \\
\hline Forest City & 4 \\
\hline Holbrook & $26^{*}$ \\
\hline Ichkala & 4 \\
\hline Kesen & 4 \\
\hline Knyahinya & 5 \\
\hline Krasnoi-Ügol & 5 \\
\hline Kuleschovka & 3.5 \\
\hline Kunashak & 4 \\
\hline Marion & 3 \\
\hline Maziba & 4 \\
\hline Mocs & 6 \\
\hline Modoc & 9 \\
\hline Mordvinovka & 6.5 \\
\hline Mount Browne & 4 \\
\hline Nanjemoy & 13 \\
\hline New Concord & 4 \\
\hline Nikolskoie & 2 \\
\hline Ochansk (1) & 5 \\
\hline Ochansk (2) & 4 \\
\hline Olivenza & 6 \\
\hline Olmedilla de Alarcon & 5 \\
\hline Pantar & 5 \\
\hline Parmallee & 3.5 \\
\hline Pervomaisky & 5 \\
\hline Pultusk & 3 \\
\hline Richardton & 4 \\
\hline Saint Michel & 4 \\
\hline Saratov & 22 \\
\hline Sautschenskoje & 4 \\
\hline Stavropol & 2.5 \\
\hline Tane & 5 \\
\hline Uberaba & 4 \\
\hline Weston & 6 \\
\hline Yatoor & 6 \\
\hline Zhovtnevyi & 6 \\
\hline
\end{tabular}

Ordinary chondrite finds

Acme

Alamagordo 26

Arriba 53

Aurora 20

Beenham 34

Berdyansk 7

Brisco County $\quad 150$

Cavour 4

Chuvashskie-Kissy 5

Colby, Kansas $\quad 170$

Coldwater 10

Coolidge 32

Covert $\quad 115$ 
TABLE 2. (Continued)

\begin{tabular}{lr}
\hline \multicolumn{1}{c}{ Meteorite } & Barium, ppm \\
\hline DeNova & 115 \\
Farley & 290 \\
Fayette County (Bluff) & 3 \\
Gladstone & 17 \\
Goodland & 10 \\
Harrisonville & 7 \\
Hayes Center & 30 \\
Hugoton & 200 \\
Kansas City & 4 \\
Kelly & 165 \\
Kingfisher & 5 \\
Ladder Creek & 94 \\
LaLande & 210 \\
Long Island & 190 \\
Marsland & 3 \\
McKinney & 6 \\
Melrose & 155 \\
Morland & 5 \\
Ness County (1894) & 20 \\
Orlovka & 18 \\
Otis & 7 \\
Petropavlovka & 4 \\
Plainview & 10
\end{tabular}

TABLE 2. (Continued)

\begin{tabular}{lc}
\hline \multicolumn{1}{c}{ Meteorite } & Barium, ppm \\
\hline Potter & 155 \\
Ransom & 28 \\
Roy & 72 \\
Rush Creek & 5 \\
Seibert & 125 \\
Texline & 13 \\
Tryon & 190 \\
Tulia & 120 \\
Wilmot & 82 \\
& \\
Carbonaceous chondrites & \\
Felix & 4 \\
Murray County & 4 \\
Achondrites & \\
Cumberland Falls & 14 \\
Johnstown & 2.5 \\
Norton County & 2 \\
Shalka & 4 \\
Shaw & 26
\end{tabular}

* Erratic results from different samples; mean of 8 samples.

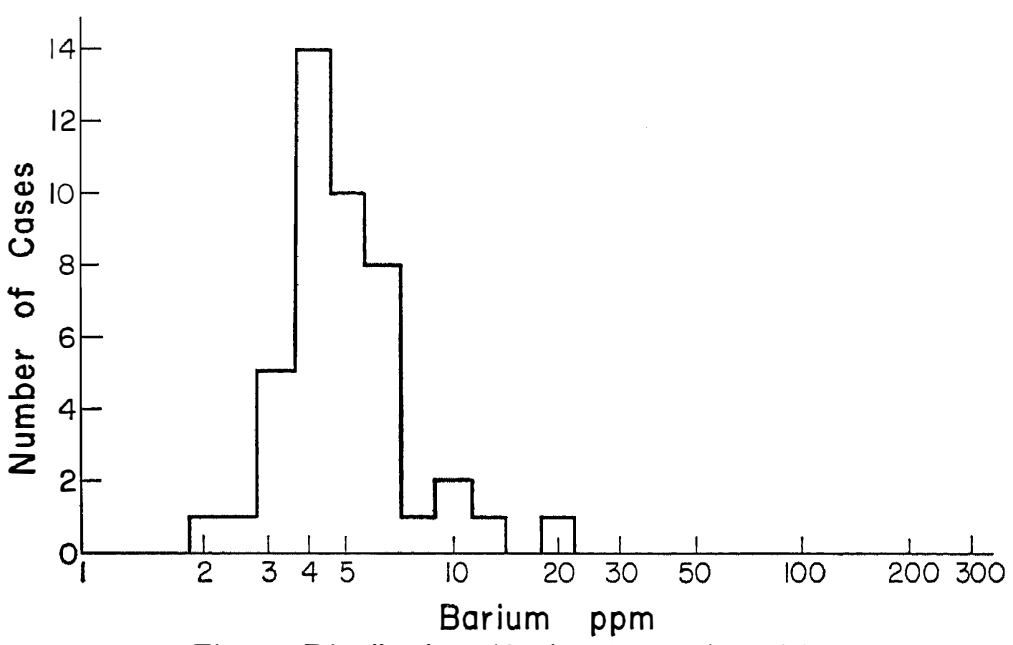

Fig. 1. Distribution of barium in chondritic falls.

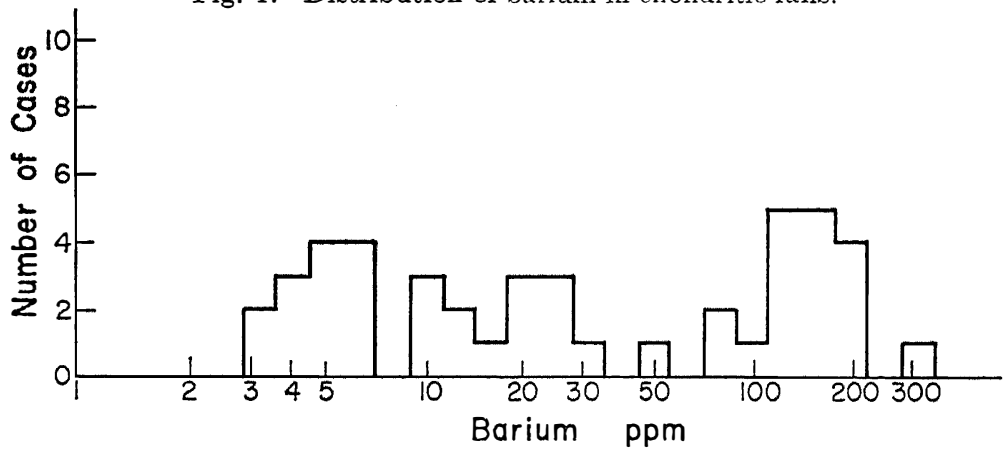

Fig. 2. Distribution of barium in chondritic finds. 
TABLE 3. Concentrations of Barium in Eight Specimens of the Holbrook Chondrite

\begin{tabular}{lc}
\hline \multicolumn{1}{c}{ Sample } & Barium, ppm \\
\hline Several pea-sized fragments, 5 grams & 28 \\
Single fragment, 1 gram & 9 \\
Mainly black fusion crust, 1 gram & 8 \\
Single complete stone & 74 \\
Fine dust from complete sample & 29 \\
Nonmagnetic phase & 24 \\
Black crust, 0.5 gram & 110 \\
Small chips from all fragments, & 27 \\
3 grams & 26 \\
$\quad$ Median & \\
\hline
\end{tabular}

one-half that given by Pinson et al. [1953] and very close to the more accurate determinations of Hamaguchi et al. [1957] which are, however, fewer in number. These data emphasize the importance of using falls instead of finds for all significant trace element work and also the importance of knowing the past history of re- corded falls, since specimens are often on the ground for some time before they are collected.

Acknowledgments. The authors express their appreciation to the National Aeronaitics and Space Administration for their financial support of this work through grant NsG-56-60.

We also wish to thank Mr. Arthur Chodos and Mrs. Elizabeth Bingham for their invaluable counsel and help in developing and carrying out the spectrographic measurements.

\section{REFERENCES}

Hamaguchi, H., G. W. Reed, and A. Turkevich, Uranium and barium in stone meteorites, Geochim. Cosmochim. Acta, 12, 337-347, 1957.

Moore, C. B., and H. Brown, The distribution of manganese and titanium in stony meteorites Geochim. Cosmochim. Acta, 26, 495-502, 1962.

Pinson, W. H., L. H. Ahrens, and M. L. Franck, The abundances of $\mathrm{Li}, \mathrm{Sc}, \mathrm{Sr}, \mathrm{Ba}$, and $\mathrm{Zr}$ in chondrites and some ultramafic rocks, Geochim. Cosmochim. Acta, 4, 251-260, 1953.

Von Englehardt, D., Die Geochemie des Barium, Chem. Erde, 10, 187-208, 1936.

(Manuscript received April 29, 1963.) 